\title{
DISPUTE ABOUT PUBLIC RELATIONS - BETWEEN SOCIAL AND MARKETING COMMUNICATION
}

\section{Sławomir Gawroński', Roland Jakubowski}

\begin{abstract}
Ever since the Kotler's promotion-mix concept based on the most traditional model of four pillars - advertising, public relations, sales promotion and direct sales has become commonly known, $P R$ has been treated as one of many, typically marketing, impact tools. This perception is particularly characteristic for the science of marketing management and publication. Meanwhile, it is often forgotten that public relations is the management of communication, which may be used in marketing communication, however it is a much broader meaningful concept, giving greater perspectives of use. This article refers to defining a place of public relations between two asymmetric areas of communication - social and marketing one. Basing on literature analysis, the authors define key factors differentiating both perspectives, they also evaluate the proposals for introducing new concepts into the media and communication terminology, indicating the distinctiveness of both conceptual categories.
\end{abstract}

Keywords: public relations, marketing communication, social communication.

Public relations, as well as en bloc communication, is identified by its exceptional interdisciplinary character, deriving from the achievements of at least several scientific disciplines and even a greater number of sub-disciplines. Depending on the context of deliberations on PR, in Polish conditions, the most common is its relationship with two disciplines, although separated and different from each other, but in many areas, however, complementing each other - in the sciences of management and the sciences of the media and social communication. In addition, there are numerous connections with such disciplines as sociology, political sciences, psychology and many others, because the universal nature of interpersonal communication and the wide range of impact that PR strategies and tools result in a diverse spectrum of practical use of public relations' achievements. This is partly due to the fact that PR, as one of the tools used in marketing, is also common in increasingly diverse areas of social activities. Marketing itself is no longer the domain of enterprises and other entities, pursuing mercantile goals and

\footnotetext{
Associate Professor in Chair of Media, Journalism and Public Relations. Mass media and political scientist. Dean of the Faculty of Administration and Social Sciences at the University of Information Technology and Management in Rzeszow. E-mail: sgawronski@wsiz.rzeszow.pl.

$2 \quad$ University of Information Technology and Management in Rzeszow.
} 
being targeted at commercial activities, and we are still dealing with its social expansion [Gawroński 2013, p. 13].

The identification of public relations with marketing is also influenced by the fact that dynamically developing new communication technologies, new media and social media are successfully used in both marketing and PR activities - sometimes being very similar to each other in the sphere of tools, as well as within their defined goals [Scott 2007]. As J. Olędzki notes, the definition of public relations varies depending on the context in which the research is carried out, it depends on time, place, professional and social group that PR is concerned with. PR is viewed differently by economists, politicians, social activists, activists of charitable organizations, ecological movements, ethnic minorities or religious groups. People with different interests, different experiences, with diverse research and material facilities, and obviously with different human potential have influence on the directions of development, the scope of activity, the choice of tools as well as the methods of impact. As a consequence, there is a lack of coherence, eclecticism and heterogeneous nature of PR research and the understanding of the needs and requirements of this discipline [Olędzki 2006, p. 26].

Many authors in Polish literature cite the opinion formulated by K. Wojcik, who, having analyzed numerous definitions of public relations, indicates that their number oscillates at around two thousand [Wojcik 2009, p. 23]. Today, there are probably even more PR definitions. A complex definition of PR is a difficult task, the multitude of definitions functioning in the literature of the subject only confirms the task. Some of the definitions are used and quoted particularly often, which may indicate their universal character and relatively correct meaning. One of the classic and the most complete definitions of PR was created in 1975 as a result of the study of almost 500 interpretations, made by 75 PR leaders in the United States.

According to it, public relations is an independent management function that helps to establish and maintain two-way communication, understanding, acceptance and cooperation between the organization and its environment; public relations helps to manage problems or issues, helps the management in getting information about the environment and reacting to it. Public relations defines and emphasizes the management's duty to serve the public interest, helps in obtaining information on changes and effective opportunities for using them, serving as an early warning system to predict trends, and moreover, as a key tool uses research as well as reliable and ethical communication techniques [Seitel 2003, pp . 9-10]. An important role in defining public relations is played by proposals developed by PR institutes and associations, which gather both theoreticians and practitioners of the issue, often turn out to be extremely competent institutions in deriving accurate definition hypotheses [Gawroński 2006, pp. 34-35]. The ambiguity connected with public relations definition affects not only the definition itself, but it also has the consequences in colloquial misunderstanding of the term - significantly different from its proper meaning. The research shows that PR in Poland is identified with marketing and sales in particular, but it is also associated with the activity of politicians, suspected of manipulating information. It also applies to journalists, the media as well as advertising. Public relations is commonly understood as self-advertising and boasting.[Olędzki 2016, pp-26-28]. Sometimes public relations is defined by task areas understood as basic areas of activity, grouping specific tools, targeted at similar recipients [Tworzydło 2017, pp. 39-41]. In terms of the number and extent of these areas, there is no full agreement among the authors, but some of them overlap in particular typology proposals, which would confirm their importance within public relations. One of the universally recognized typologies of PR areas of action is the concept by D. Wilcox, P. Ault and W. Agee, assuming a division into 15 basic spheres: [Wilcox et. al. 1998, pp. 10-11] research, consulting, media relations, publicity, relations with employees or members (internal relations), relations with the community (community relations), public affairs, government affairs, issues management, financial relations, industrial relations, raising 
funds, special events, special relations, marketing communication. These spheres of activity are usually divided into internal public relations areas and a much more developed area of PR focused on external environmental entities. Defining public relations by indicating the tool groups of influence on specific collectives is justified, but it reflects only the instrumental nature of the procedures in the communication with target audiences, but the understanding the essence of the phenomenon becomes only slightly more comprehensible.

The scientific division of the four main public relations models used in the practice of communication activity is still based on classical research and the work of J. E. Grunig and T. Hunt. The theory of PR models developed by them [Gruning, Hunt 1984, p. 21] combined with the theory of recipient groups became the basis of contemporary public relations scientific theory. They, along with the development of tools and communication techniques, are constantly being expanded.

Two other commonly used public relations models: personal influence and cultural interpreter / interpreter [Płonkowski 2002, pp. 62-65]. have been developed on the basis of empirical research, conducted in India, Greece and Taiwan. Nowadays, one of the most commonly used ones is the model of perfect public relations, created on the basis of the works of J. E. Gruning, D. M. Dozier, W. P. Ehling and F. C. Repper. This model changes and partly separates itself from commonly known and often cited models from the 1980s. It describes the way in which participating parties act as cooperating opponents who want to achieve their own subjective goals in the communication process, but at the same time are interested in building long-term cooperation and stable relations [Gruning et al. 1996, pp. 199-228]. The model of excellent public relations is considered as one of the milestones in research on PR communication, due to the partial undermining of simplified concepts that had been worked out earlier as well as due to its creative indication to build new theories [Zerfass 1996, pp. 18-21].Empirical research on a model of perfect public relations prompt us to be convinced about the strategic nature of PR, with an important role in every organization [Gruning 2011, pp. 11-28].

J. Olędzki comes to the conclusion which influences the differentiation of marketing and public relations impact in the organization. "Marketing works only in a linear function, and public relations is irreplaceable in the employee function (advising), in other words, in a thriving company marketing is a tactic, public relations is a strategy." [Olędzki 2011, p. 13]. This statement is part of the ongoing discussion concerning on the differentiation of marketing and $\mathrm{PR}$, and taking into account the role of public relations performed not only in marketing communication, but also - in social communication.

As it had been already mentioned, public relations is treated only as a form of promotion, a group of communication tools that appear within the marketing communication pursuing market goals of enterprises. These goals may concern both brand building, creating the image of commercial and non-commercial market entities, as well as stimulating sales. This way of thinking, characteristic especially for economists, can be found in classic marketing textbooks. P. Kotler combines public relations with publicity and treats them as one of the four basic elements of the marketing communication system (promotion mix), parallel to advertising, direct marketing and sales promotion [Kotler 1997, p. 546]. At the same time, he points out the key features of PR which, in his opinion, determine the effectiveness within marketing interactions, such as: [Kotler 1997, pp. 563-564] high credibility (general messages seem more authentic and trustworthy for recipients than advertising), surprise (public relations can reach many customers avoiding advertising and contact with sellers.

The message reaches the buyers as part of general news, not as commercial information), distinction (public relations, like advertising, has the ability to promote a given company or product). D. Tworzydło argues that the basic difference between public relations and advertising is the fact that advertising is a promotional message, while public relations is based on objective based communication and built on the truth. In contrast 
to advertising, PR does not try to sell anything, but it can influence the beliefs and shape the imaginations based on real data and premises in the audience's consciousness. Of course, there are many more differences between the two forms of marketing communication [Tworzydło 2017, pp. 26-27]. K. Przybyłowski, SW Hartley, RA Kerin and W. Rudelius also place public relations as one of four key elements within the promotional mix, treating PR as a form of marketing communication management, the purpose of which is to influence the image of an organization, its products or services, not limiting only to segments of the target market, but going far beyond this framework and in practice directed to the whole society [Przybyłowski et al. 1998, p. 488].

A. Szymańska emphasizes that the relationship between marketing and public relations has always been unclear and controversial, and this ambiguity results from the difficulties in defining the roles and boundaries of both fields [Szymańska 2006, pp. 184185]. The treatment of public relations exclusively through the prism of the connections of this form of social communication with the marketing goals and impacts is assessed by J. Olędzki as a mistake. He points out the negative accepts noticing only of the effectiveness of marketing public relations, while completely ignoring the non-marketing significance of PR activities and social philosophy of public relations [Olędzki 2006, pp. 32-37]. Meanwhile, PR should be treated as an independent scientific field, independent of marketing (unlike other marketing tools used in marketing) [Olędzki 2011, p. 12].

A certain solution to this definition dispute was the attempt to introduce and popularize the term of public relations marketing, which distinguishes this sphere of activities from the wider notion of simply public relations (sometimes also called corporate public relations - CPR). Such a formula really allows assigning specific marketing functions to the impact of public relations, without narrowing down the semantic term, which is PR, but the indicated division is not universally applicable in both the literature of the subject and the environmental discourse. Marketing public relations is therefore treated as a narrower aspect of PR, involving interaction with clients and other audience groups in relation to marketing content in order to directly support the promotion of the company and the product, shaping the image, communicating reliable information, and supporting social useful activities. Its essence is to stimulate the clients' awareness of the company and its products, generate sales growth, facilitate communication and build relationships between clients, companies and brands [Olędzki 2011, p. 189]

Figure 1. Model of relations between marketing, public relations and marketing public relations.

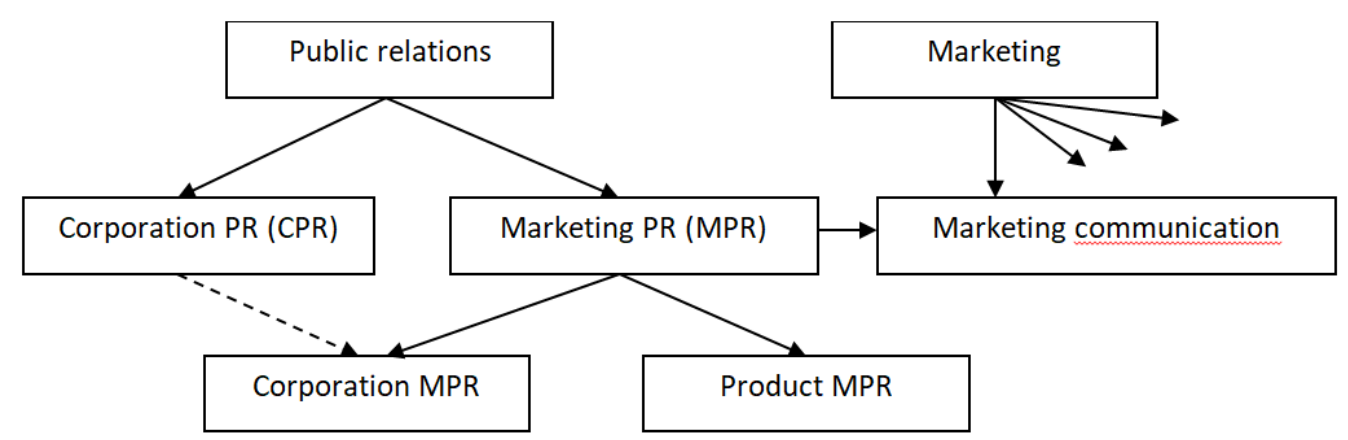

One should agree with the possibility of identifying a specific public relations marketing formula, but the corporate PR design is artificial and complicates the model of the relationship between marketing and PR unnecessarily. Extending it with MPR and CPR is intensified by introducing yet another category - CMPR (Corporate Public Relations) corporate marketing public relations. Separating PR from public relations seems to be a sufficient step in the right direction, fully differentiating the business and non-business 
spheres of public relations. The concept of marketing public relations appears in the literature usually in the immediate vicinity of the term: integrated marketing communication. These terms are even treated as synonyms. This is due to the fact that for many practitioners, PR marketing is basically identical with the promotion mix, and thus, it is a binder that combines various communication and promotional tools. Integrated marketing communication is also a kind of a "clip" of a diverse resource of promotional tools, enriched with assumptions regarding their combination and cooperation in the implementation of marketing strategies. Thus, it is a relatively new philosophy of thinking about old and well-known marketing communication tools.

In order to summarize the deliberations concerning marketing and non-marketing public relations functions, the following areas should be mentioned within the PR marketing: building brand awareness (product, service, company), creating (changing, consolidating) brand image, building relationships with the environment (stimulating customer loyalty), stimulating sales, grouping other influences within the scope of marketing communication, strengthening the company's competitive position on the market, creating a friendly atmosphere around the company, enabling its development.

In relation to public relations functions that reach beyond the area of interest of economists, it is necessary to list those that relate to the essence of PR, and hence social communication. They include, inter alia: passing messages, creating a community during communication and as a result of it, bringing people and their opinions together, stimulating interpersonal cooperation, stimulating social trust, creating and strengthening social relations.

The general description of functions of social public relations allow the adaptation in many fields - everywhere where PR activities are carried out. Even with regard to production companies, public relations should significantly go beyond the sphere of business marketing and mercantile goals. As Olędzki observes, PR activities as a socially oriented communication of an enterprise always shows a wider context of the activity of each organization. All PR theory and practice consists of communicating - not communicating something to someone, but communicating with someone. It is, therefore, a two-way process, the aim of which is to communicate, accept and have a dialogue based on the recognition of everybody's right to co-exist. Thus, PR is a testimony to the spirit of reconciliation, an instrument of friendship and respect for people with whom we want to work and develop [Olędzki 2006, pp. 34-35].

Marketing and non-marketing public relations functions can be observed in the analogical diversity of specific functions of individual PR areas. Media relations can serve as an example of the issue. Cooperation and building relationships with journalists, as well as the use of mass communication within communication activities conducted by the organization can be purely mercantile, aimed at building a brand, promoting a product or creating a company's image. It can also go beyond these goals. Mass media can therefore be used as an intermediary in communication between the organization and its surroundings. Their specific character, strengthened by growing interactivity, enables a dialogue with diverse reference groups. Contemporary media relations are not communicating content using mass media to mass audiences, but the actual process of bilateral communication, resulting, inter alia, from the control function of mass media and their ability to diagnose public sentiment. The variety of mass communication means also gives the possibility to adjust more adequately to the expectations and preferences of recipients, which improves relations and the effectiveness of communication contacts.

A contemporary view on public relations assumes that it is primarily a social communication that can be used for the needs of marketing interactions, although sometimes it is difficult to indicate a clear border, where marketing begins, and where we deal with the process of social communication only. Communicating, as the essence of public relations interactions, is manifested, inter alia, in the fact that they are conducted at all levels of communication, indicated in the pyramid D. McQuail [McQuail 2007, p. 36]. 
Another argument is the fact that public relations is used by a variety of people, institutions and organizations, in a way not related to business and not focused on achieving marketing goals - not only those connected with sales, but also with the image of a company. Public relations often serves the aim which constitutes its essence -namely building correct relationships, creating an atmosphere of acceptance, cooperation and mutual trust. Similarly to public relations in business marketing, as well as in the reference to non-economic, sector forms of marketing, PR activity has got both communication and marketing functions.

\section{References:}

GAWROŃSKI S., Media relations. Współpraca dziennikarzy I specjalistów PR., Wydawnictwo WSliz, Rzeszów 2006.

GAWROŃSKI S., Pozabiznesowe obszary wykorzystywania komunikacji marketingowej w warunkach polskich. Wybraneaspekty, Aspra, Warszawa 2013.

GRUNIG J. E., Public relations and strategic management. Institutionalizing organization - public relationships in contemporary society, "Central European Journal of Communication”, Nr 4/2011.

GRUNING J. E. , GRUNING L. A., DOZIER D. M., Das situative Modell exzellenter Public Relations. Schlußfolgerungen aus einer internationalen Studie, [w:] Bentele G., Steinmann H., Zerfass A., Dialogorientierte Unternehmenskommunikation. Grundlagen, Praxiserfhrungen, Perspektiven, Vistas, Berlin 1996.

GRUNING J. E., HUNT T., Managing Public Relations, Holt, Rinehart and Winston, Nowy Jork 1984. KOTLER P., Marketing. Analiza, planowanie, wdrażanie i kontrola, Gebethner i S-ka, Warszawa 1997.

MCQUAIL, Teoria komunikowania masowego, PWN, Warszawa 2007.0lędzki J., 0 wizerunku public relations w polskim społeczeństwie, „Studia Medioznawcze”, Nr 1/2016.

OLĘDZKI J., Preambuła o public relations. Między służbą organizacji i społeczeństwu, w: J. Olędzki (red.), Public relations we współczesnym świecie. Między służbą organizacji i społeczeństwu, ASPRA-JR, Warszawa 2011.

OLĘDZKI J., Public relations w komunikacji społecznej, [w:] J. Olędzki, D. Tworzydło (red.), Public relations. Znaczenie społeczne i kierunki rozwoju, PWN, Warszawa 2006.

PICKTON D., BRODERICK A., Integrated Marketing Communications, Prentice Hall, Harlow 2005.

PŁONKOWSKI T., Modele public relations - historia, ewolucja, przyszłość, „Studia Medioznawcze”, Nr 3/2002. PRZYBYŁOWSKI K. et al., Marketing. Pierwsza Polska Edycja, ABC, Warszawa 1998.

SCOTT D. M., The New Rules of Marketing and PR. Ho to use news releases, blogs, podcastings, viral marketing and online media to reach buyers directly, John Wiley \& Sons, Hoboken 2007.

SEITEL F. P., Public relations w praktyce, Feldberg, Warszawa 2003.

SZYMAŃSKA A., Zintegrowane komunikowanie marketingowe, [w:] J. Olędzki, D. Tworzydło (red.), Public relations. Znaczenie społeczne i kierunki rozwoju,PWN, Warszawa 2006.

TWORZYDŁO D., Public relations. Praktycznie, Newsline, Rzeszów 2017.

WILCOX D., AULT P., AGEE W., Public Relations. Strategies and Tactics, New York 1998.

WOJCIK K., Public relations, wiarygodny dialog z otoczeniem, Placet, Warszawa 2009.

ZERFASS A., Was ist exzellente PR? Ergebnisse des weltweit größten Forschungsprogramms, "PR Forum", Nr 3/1996. 